\title{
Cyprideis torosa (Jones, 1850) in its type area and stratigraphical context: potential for mapping the freshwater/estuarine boundaries of the Thames-Medway river system in the MIS 9 and MIS 11 interglacials
}

\author{
David J. Horne ${ }^{*}$, Ginny Benardout ${ }^{1}$ \& John E. Whittaker ${ }^{2}$ \\ ${ }^{1}$ School of Geography, Queen Mary University of London, Mile End Road, London E1 4NS, UK \\ ${ }^{2}$ Department of Palaeontology, The Natural History Museum, Cromwell Road, London SW7 5BD, UK \\ *Correspondence: d.j.horne@qmul.ac.uk
}

\begin{abstract}
This study explores the potential of the ostracod Cyprideis torosa (Jones, 1850) as a brackish-water indicator for mapping freshwater/estuarine boundaries in Pleistocene interglacials in SE England. Ostracod species records from MIS 9 (Purfleet) and MIS 11 (Hoxnian) interglacial sites are mapped onto established palaeogeographies of the Thames-Medway river system, revealing distribution patterns indicative of a salinity gradient from west (freshwater) to east (brackish estuarine) in both cases. Comparisons with the ostracod biofacies of the present-day Thames Estuary suggest there may be no exact modern analogue for the Thames/Medway palaeoenvironments of the MIS 9 and MIS 11 interglacials. A similar conclusion is drawn from discussion of noding in C. torosa, which is common in the interglacial assemblages but extremely rare in the modern estuary. The value of mapping $C$. toros $a$ onto estuarine palaeogeography is limited by taphonomic considerations because postmortem transport and mixing in a macrotidal estuary significantly influence the composition of ostracod assemblages. Nevertheless, its use in combination with other brackish-water taxa provides useful insights regarding the palaeosalinity regimes of the lower River Thames and River Medway during the MIS 9 and MIS 11 interglacials.
\end{abstract}

Keywords: Ostracoda; Pleistocene; salinity; palaeogeography; England

Received 11 October 2015; accepted 14 January 2016

In $1850 \mathrm{~T}$. Rupert Jones described eight ostracod species, five of them new, from supposed Pleistocene sediments at Newbury (Berkshire) and Copford, Clacton and Grays (all in Essex). At Grays (the precise locality is, unfortunately, not known) he recorded six species: Cypris tumida sp. nov., Cypris gibba Ramdohr, Candona lucens Baird, Candona reptans (Baird), Candona torosa sp. nov. and ?Cythere trigonalis var. laevis sp. et var. nov.. Within a few years he had revised his nomenclature a little (Jones 1857). Cypris tumida he now considered a variety of Cypris browniana (originally described also in 1850 by Jones, but from Clacton), he had synonymized Candona lucida with C. candida (O.F. Müller), and he placed Candona torosa into his new subgenus Cyprideis. It was not until later (Jones \& Sherborn 1889) that Jones considered his ? Cythere trigonalis var. laevis to be a species of Potamocypris. He originally described Cyprideis as a subgenus of Candona (a cypridoidean). Although he suspected already that it would 'prove to be a Cythere' (Jones 1857, p. 20), in other words a cytheroidean, he was unable to confirm this at the time because he had been unable to examine the appendages of any living specimens (although he was aware of at least one living population on the southern coast of the Thames Estuary near Gravesend). Candona torosa Jones, 1850, being the only species assigned to the new genus in its original description, is automatically the type-species of Cyprideis.

Cyprideis torosa was subsequently transferred to the genus Cytheridea by Brady et al. (1874) who included in it Cytheridea torosa var. teres, introduced by Brady \& Robertson (1870) for the un-noded form and being the equivalent of Cyprideis littoralis, described by Brady (1868) from salt marshes in NE England ( $C$. torosa var. torosa being the noded form); this assignment was accepted by Jones \& Sherborn (1889). The genus Cyprideis, subsequently recognized as distinct, is now well established and in common use (see Kilenyi \& Whittaker 1974, who designated and illustrated a lectotype of C. torosa).

Today Jones' six species from the Pleistocene of Grays would be recognized under the following combinations:

$$
\begin{aligned}
& \text { Cypris tumida }=\text { Scottia tumida }(\text { Jones }) \\
& \text { Cypris gibba }=\text { Ilyocypris gibba }(\text { Ramdohr) }
\end{aligned}
$$

Candona lucens $=$ ?? [although synonymized by Jones (1857) himself with Candona candida (O.F. Müller), and accepted by Griffiths (1995), the original drawing looks more like a specimen of Candona neglecta Sars, which has been found by us in collections from Grays; Baird's name would be the senior synonym, but as no type specimens are available it must remain uncertain.]

\section{Candona torosa $=$ Cyprideis torosa (Jones)}

?Cythere trigonalis var. laevis $=$ Potamocypris sp. [Griffiths (1995, p. 133) is correct in stating that the species cannot be identified from Jones' original illustration alone].

The deposits from which these ostracods were collected occupy a former channel of the River Thames (Lynch Hill/Corbets Tey terrace) and are now assigned to the Marine Isotope Stage (MIS) 9 'Purfleet' Interglacial (Penkman et al. 2013). The assemblage is essentially of freshwater character with the exception of C. torosa, now one of the best-known and most-studied of all ostracods and commonly regarded as an indicator of brackish water.

The aim of the present study is to explore the potential of $C$. torosa, as an indicator of low-salinity brackish-water palaeoenvironments, for mapping the boundaries between freshwater and 
estuarine water in the Thames-Medway river system in Pleistocene interglacials. A database of ostracod species records has been compiled from ten fluvial sites representing the MIS 9 (Purfleet) interglacial, including Grays (the type locality and horizon of $C$. torosa), as well as four fluvial sites representing the MIS 11 (Hoxnian) interglacial. In addition, the lacustrine MIS 11 site at Marks Tey is included because it holds an enigmatic record of $C$. torosa; note, however, that available records from this site most likely do not represent the Hoxnian interglacial but the transition into the succeeding cold stage (Horne et al. 2014).

\section{Methods}

We compiled a database of ostracod records from Pleistocene interglacial sites in SE England and used it to map the distributions of C. torosa and other species selected for their palaeosalinity implications, using a Geographical Information System (DIVAGIS, version 7.5.0; Hijmans et al. 2001). Most of the ostracod records were obtained from published literature, but a few are from our own as-yet-unpublished data (see Table 1 for sources). We focused on two interglacials, MIS 9 and MIS 11, because the former includes the type locality and horizon of $C$. torosa and detailed palaeogeographical reconstructions based on palaeochannels are available for both (Bridgland et al. 1999; Schreve et al. 2002; Roe \& Preece 2011). A summary map of modern ostracod biofacies in the Thames Estuary was constructed for comparison with the fossil distributions, using data from Kilenyi (1969). In the absence of evidence to the contrary the fossil ostracod records were assumed to represent in situ occurrences, not subjected to significant postmortem transport, and thus representative of local conditions. This assumption could be validated in a few cases (e.g. MIS 9 Purfleet and Cudmore Grove) by the evidence of a range of adults and juveniles demonstrating autochthonous thanatocoenoses (Boomer et al. 2003) but in others there was insufficient evidence to rule out the possibility of transported assemblages such as are common in the modern Thames Estuary. Salinity range information for ostracod indicator taxa was compiled from the available literature.

\section{Salinity ranges of selected ostracod taxa}

Salinity ranges reported in the literature must be treated with a certain amount of caution and attention to the environmental settings in which they were recorded. The salinity ranges of species inhabiting stable brackish waters where there is little variation may be quite different from those of the same species living in a tidal estuary (where marked tidal and/or seasonal fluctuations are experienced) (Smith \& Horne 2002). In the stable regime of the Gulf of Finland (Baltic Sea) a number of freshwater taxa are able to extend their distribution into waters of low salinity (Hagerman 1967) where they co-exist with true brackish and marine-brackish species, but this does not provide a valid model for the interpretation of the macrotidal Thames Estuary. The known salinity preferences of the selected indicator taxa are summarized below.

\section{Cyprideis torosa (Jones)}

This species typically lives mainly in brackish waters connected to marine waters and experiencing significant salinity fluctuations; in certain settings, such as intertidal saltmarsh pools, it can achieve extremely high population densities. It has a wide salinity tolerance, from freshwater to hypersaline (c. 60\%o), but seems to thrive particularly in low-brackish salinities $(2-16.5 \%)$; reports of inland freshwater lake occurrences may be misleading as at least some have been shown to be slightly brackish (Athersuch et al. 1989; Horne \& Boomer 2000; Meisch 2000). Variable carapace noding in this species is regarded as an indication of low-salinity brackish environments and increases with decreasing salinity, though observations of the actual salinities at which these changes occur are somewhat inconclusive. In microcosm experiments, Frenzel et al. (2012) showed a negative linear correlation between salinity and proportion of noded individuals, with a marked increase in the latter below 5-6 (practical salinity units; equivalent to \%o). Field data from the same study found a dominance of noded values from around 2, while other compared studies suggest dominance between 2 and 5. Pint et al. (2012) advise caution when attempting to reconstruct absolute salinities, instead suggesting that $C$. torosa may be more effectively used to reconstruct palaeosalinity trends.

\section{Cytheromorpha fuscata (Brady)}

This appears to be a brackish-water ostracod that also tolerates fresh water. A synthesis of many works on Cytheromorpha fuscata is provided by Neale \& Delorme (1985; see also references therein), who considered it a brackish-water ostracod found in estuarine and shallowmarine environments, with an upper salinity limit of about 20\%o, but noted that it has been found in freshwater $(<1 \%)$. They noted its occurrence in freshwater in Finland, citing Alm $(1912,1916)$, but nevertheless considered their own new records of it from inland freshwater lakes in Canada to be 'unique', and suggested the presence of sodium chloride-rich brine discharges to be a key factor in the continued existence of C. fuscata in the Canadian lakes. Sars (1925) recorded it in Norway in the entrance to Drammen Fjord at Svelvik, where the surface water was almost fresh, in association with the brackish/estuarine Leptocythere castanea. Hagerman (1967) reported it as a true brackish-water species living in the Gulf of Finland in salinities of $1-7 \%$, varying with depth and proximity to the coast. There is only one living record in the UK (Norfolk), from a freshwater lake with brackish incursions on spring tides (Boomer \& Horne 1991). According to Elofson (1969) it is a strictly brackish-water form not found in waters with salinity above $18 \%$. McKillop et al. (1992) reported on its association with chloride-dominated saline spring waters in the inland Lake Winnepegosis, Canada, together with other ostracods and foraminifera (including Jadammina macrescens (Brady), a well-known coastal saltmarsh species); although two ostracod species (Limnocythere staplini Gutentag \& Benson and Sarscypridopsis aculeata (Costa)) were collected alive in saline sites, C. fuscata was found only living in a single, freshwater site. Despite this finding they referred to it as a 'coastal marine' species, citing Neale \& Delorme (1985) and noted that occurrences of empty shells at two Lake Winnepegosis sites probably represented reworking of older marine-brackish-water sediments. In the Holocene of the Baltic Sea coast of Poland it was recorded as a monospecific assemblage considered to represent brackish water heralding a marine transgression (Krzymińska \& Namiotko 2012).

\section{Sarscypridopsis aculeata (Costa)}

This species prefers brackish coastal pools (permanent or temporary) up to about $17 \%$ with the optimum around $5-10 \%$; it is rare in fresh water (Meisch 2000). As noted above, McKillop et al. (1992) recorded it alive in saline waters in an inland Canadian lake.

\section{Loxoconcha elliptica Brady}

A true brackish-water species, common in saltmarsh creeks, with an optimum salinity range of $10-20 \%$ although it can tolerate lower and higher salinities for short periods (Theisen 1966; Horne \& Boomer 2000).

\section{Leptocythere spp.}

British Leptocythere species have wide salinity tolerances and although they can be valuable palaeosalinity indicators on account 
Table 1. Records of ostracod taxa in the Pleistocene deposits assigned to MIS 9 and MIS 11 in the Thames-Medway region

\begin{tabular}{|c|c|c|c|c|c|c|c|c|c|c|c|c|c|c|c|}
\hline \multirow[b]{2}{*}{ Ostracod taxa } & \multicolumn{5}{|c|}{ MIS9 sites } & \multirow[b]{2}{*}{ Shoeburyness } & \multicolumn{9}{|c|}{ MIS11 sites } \\
\hline & Hackney & $\begin{array}{l}\text { Belhus } \\
\text { Park }\end{array}$ & Purfleet & Grays & Allhallows & & Barling & Canewdon & $\begin{array}{l}\text { North } \\
\text { Wick }\end{array}$ & $\begin{array}{l}\text { Cudmore } \\
\text { Grove }\end{array}$ & Swanscombe & Ebbsfleet & $\begin{array}{l}\text { East } \\
\text { Hyde }\end{array}$ & Clacton & $\begin{array}{l}\text { Marks } \\
\text { Tey }\end{array}$ \\
\hline Candona angulata G.W. Müller & & & $\mathbf{F}$ & & & & $\mathbf{F}$ & & & & & & & $\mathbf{F}$ & $\mathbf{F}$ \\
\hline Candona candida (O.F. Müller) & $\mathbf{F}$ & & $\mathbf{F}$ & $\mathbf{F}$ & & & & & & & & & & & $\mathbf{F}$ \\
\hline Candona neglecta Sars & $\mathbf{F}$ & & $\mathbf{F}$ & & $\mathbf{F}$ & $\mathbf{F}$ & $\mathbf{F}$ & $\mathbf{F}$ & $\mathbf{F}$ & $\mathbf{F}$ & $\mathbf{F}$ & $\mathbf{F}$ & $\mathbf{F}$ & $\mathbf{F}$ & $\mathbf{F}$ \\
\hline Candona $s p$ & $\mathbf{F}$ & & $\mathbf{F}$ & & & & & & & $\mathbf{F}$ & & & F & F & \\
\hline
\end{tabular}

Candonopsis scourfieldi Brady

Cyclocypris laevis (O.F. Müller)

F

Cyclocypris ovum (Jurine)

Cyclocypris serena (Koch)

Cypria ophtalmica (Jurine)

Cyprideis torosa (Jones)

Cypridopsis hartwigi G.W. Müller

Cypridopsis vidua (O.F. Müller)

Cypris pubera (O.F. Müller)

Cyprois marginata (Strauss)

Cytherissa lacustris (Sars)

Cytheromorpha fuscata (Brady)

Darwinula stevensoni (Brady \& Robertson)

Dolerocypris fasciata (O.F. Müller)

Eucypris dulcifons Diebel \& Pietrzeniuk

Eucypris elliptica (Baird)

Eucypris pigra (Fischer)

Eucypris $s p$

Fabaeformiscandona balatonica (Daday)

Fabaeformiscandona caudata (Kaufmann)

Fabaeformiscandona levanderi (Hirschmann)

Fabaeformiscandona siliquosa (Brady)

Herpetocypris reptans (Sars)

Herpetocypris sp

Heterocypris salina (Brady)

Heterocypris sp.

Ilyocypris bradyi Sars

Ilyocypris cf grabschuetzi (Fuhrmann \& Pietrzeniuk)

Ilyocypris cf monstrifica (Norman)

Ilyocypris decipiens (Masi)

Ilyocypris gibba (Ramdohr)

Ilyocypris inermis Kaufmann

Ilyocypris lacustris (Kaufmann)?

Ilyocypris lacustris (Kaufmann)

Ilyocypris quinculminata (Sylvester-Bradley)

Ilyocypris salebrosa Stepanaitys

B
F
F
F
F
F
F
F

$\begin{array}{cccccc}\text { B } & \text { B } & \text { B } & \text { B } & \text { B } & \text { B } \\ \text { F } & \text { F } & \text { F } & & & \text { F } \\ \text { F } & & & & & \\ & & \text { F } & \text { F } & \text { F } \\ & \text { B } & & \text { B } & \text { B } \\ \text { F } & \text { F } & \text { F } & \text { F } & \text { F }\end{array}$

$\mathbf{F}$

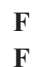

F

F

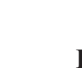

F

F
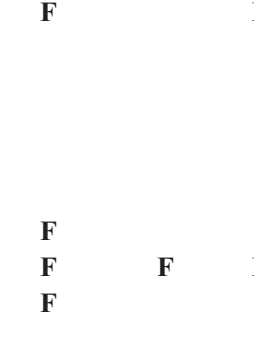

F

F

F

B

B

B

F

F

$\begin{array}{lll} & \text { F } \\ \text { B } & \text { B }\end{array}$

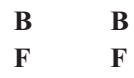

F

F

F

F

F

F

F F F

B $\quad$ B

F F




\begin{tabular}{|c|c|c|c|c|c|c|c|c|c|c|c|c|c|c|c|}
\hline \multirow[b]{2}{*}{ Ostracod taxa } & \multicolumn{5}{|c|}{ MIS9 sites } & \multirow[b]{2}{*}{ Shoeburyness } & \multicolumn{9}{|c|}{ MIS11 sites } \\
\hline & Hackney & $\begin{array}{l}\text { Belhus } \\
\text { Park }\end{array}$ & Purfleet & Grays & Allhallows & & Barling & Canewdon & $\begin{array}{l}\text { North } \\
\text { Wick }\end{array}$ & $\begin{array}{l}\text { Cudmore } \\
\text { Grove }\end{array}$ & Swanscombe & Ebbsfleet & $\begin{array}{l}\text { East } \\
\text { Hyde }\end{array}$ & Clacton & $\begin{array}{l}\text { Marks } \\
\text { Tey }\end{array}$ \\
\hline Ilyocypris sp & & & & & & & & & & & $\mathbf{F}$ & & & & $\mathbf{F}$ \\
\hline Leptocythere castanea (Sars) & & & & & & & & & B & & & & B & & \\
\hline Leptocythere pellucida (Baird) & & & & & & & B & & & & & & & & \\
\hline $\begin{array}{l}\text { Leucocythere batesi Whittaker \& Horne (L. mirabilis } \\
\text { (Kaufmann)?) }\end{array}$ & & & & & & & & & & & & & & & $\mathbf{F}$ \\
\hline Leucocythere sp & & & & & & & & & $\mathbf{F}$ & & & & & & \\
\hline Limnocythere falcata (Diebel) & & & & & & & $\mathbf{F}$ & & & & & & & & $\mathbf{F}$ \\
\hline Limnocythere inopinata (Baird) & $\mathbf{F}$ & $\mathbf{F}$ & $\mathbf{F}$ & & $\mathbf{F}$ & $\mathbf{F}$ & $\mathbf{F}$ & $\mathbf{F}$ & $\mathbf{F}$ & $\mathbf{F}$ & & & $\mathbf{F}$ & & $\mathbf{F}$ \\
\hline Limnocythere suessenbornensis (Diebel) & & & & & & & & & & & & & & & $\mathbf{F}$ \\
\hline Limnocytherina sanctipatricii (Brady \& Robertson) & & & & & & $\mathbf{F}$ & & & & $\mathbf{F}$ & & & & & $\mathbf{F}$ \\
\hline Loxoconcha elliptica Brady & & & & & & B & & & & & & & & B & \\
\hline Metacypris cordata (Brady \& Robertson) & & & $\mathbf{F}$ & & & $\mathbf{F}$ & $\mathbf{F}$ & & & & $\mathbf{F}$ & & & $\mathbf{F}$ & $\mathbf{F}$ \\
\hline Paralimnocythere compressa (Brady \& Norman) & & & & & & $\mathbf{F}$ & $\mathbf{F}$ & & & $\mathbf{F}$ & $\mathbf{F}$ & & $\mathbf{F}$ & & \\
\hline Paralimnocythere sp. & & & & & & & & & & & & & & & $\mathbf{F}$ \\
\hline Potamocypris aff. producta (Sars) & & & & & & & & & & & & & & $\mathbf{F}$ & \\
\hline Potamocypris cf arcuata (Sars) & & & & & & & & & & & & & & & $\mathbf{F}$ \\
\hline Potamocypris trigonalis var. laevis (Jones) & & & & $\mathbf{F}$ & & & & & & & & & & & \\
\hline Potamocypris villosa (Jurine) & $\mathbf{F}$ & & & & & & & & & & & & & & \\
\hline Potamocypris zschokkei (Kaufmann) & & & & & & & & & & & $\mathbf{F}$ & $\mathbf{F}$ & & $\mathbf{F}$ & \\
\hline Potamocypris sp. & & & & & & & & & & & & & & & F \\
\hline Prionocypris zenkeri (Chyzer \& Toth) & & & & & & & & & & & & $\mathbf{F}$ & & $\mathbf{F}$ & $\mathbf{F}$ \\
\hline Pseudocandona albicans (Brady) & & & & & & & & & & & $\mathbf{F}$ & & & & \\
\hline Pseudocandona compressa (Koch) & & & & & & & $\mathbf{F}$ & & & & & & & & $\mathbf{F} ?$ \\
\hline Pseudocandona marchica (Hartwig) & $\mathbf{F}$ & & $\mathbf{F}$ & & & $\mathbf{F}$ & & $\mathbf{F}$ & & $\mathbf{F}$ & & & & & \\
\hline Pseudocandona rostrata (Brady \& Norman) & $\mathbf{F}$ & & & & & & & & & & & & & & \\
\hline Pseudocandona sarsi (Hartwig) & $\mathbf{F}$ & & & & & & & & & & & & & & \\
\hline Pseudocandona sp & & & $\mathbf{F}$ & & & & & & & & & & & & \\
\hline Sarscypridopsis aculeata (Costa) & & & & & & & & & & B & & & & B & \\
\hline Scottia browniana (Jones) & & & $\mathbf{F}$ & & & & & & & & $\mathbf{F}$ & & $\mathbf{F}$ & $\mathbf{F}$ & \\
\hline Scottia tumida (Jones) & & & $\mathbf{F}$ & $\mathbf{F}$ & & & $\mathbf{F}$ & & & & & & & & \\
\hline
\end{tabular}

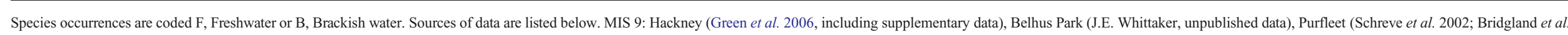

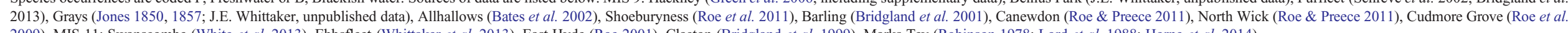
2009). MIS 11: Swanscombe (White et al. 2013), Ebbsfleet (Whittaker et al. 2013), East Hyde (Roe 2001), Clacton (Bridgland et al. 1999), Marks Tey (Robinson 1978; Lord et al. 1988; Horne et al. 2014). 
of their different salinity ranges, previous taxonomic confusion makes the application of such knowledge difficult in cases where specific identifications cannot be verified by reference to illustrations. For example, L. castanea, a common saltmarsh species, is tolerant of salinities ranging from almost freshwater to fully marine (2-35\%), while $L$. pellucida and L. tenera are exclusively marine (Athersuch et al. 1989; Horne \& Boomer 2000). Freshwater occurrences of Leptocythere species (e.g. in Lake Ohrid, Macedonia) are now considered to belong to the related genus Amnicythere (Namiotko et al. 2012).

\section{Distribution of salinity indicator taxa in the Thames- Medway in MIS 9 and MIS 11}

The mapping of the selected salinity indicator taxa onto the Thames palaeogeographies for MIS 9 and MIS 11 (Fig. 1) reveals distribution patterns that can be interpreted in terms of a salinity gradient from west (freshwater) to east (brackish estuarine) in both cases, consistent with other evidence including the general westeast flow direction of the palaeo-Thames and the relative proximity of the marine North Sea to the NE. Predominantly freshwater assemblages from all ten MIS 9 sites (Fig. 1) include C. torosa, with C. fuscata also present in both the River Thames and River Medway at two of the five most upstream localities of the palaeochannel. At Purfleet, C. torosa constitutes $c$. $50 \%$ of the assemblage in some samples (Schreve et al. 2002). Additional species indicative of brackish water appear in assemblages downstream from the Thames/Medway confluence, with L. elliptica present at Shoeburyness (6), Leptocythere spp. present at Barling (7) and North Wick (9), C. fuscata present again at Canewdon (8) and $S$. aculeata present at the northernmost MIS9 site, Cudmore Grove (10), which is interpreted as a tributary of the Thames.

Although there are fewer assemblages from MIS 11, the data similarly show an increased diversity of brackish-water indicators downstream. At the furthest upstream site, Swanscombe (11), $C$. torosa is present in an otherwise freshwater assemblage; at the nearby site of Ebbsfleet (12), the assemblage contains freshwater ostracods only. East Hyde (13) and Clacton (14) possess distinctly more numerous brackish-water indicator species, with $C$. torosa, $C$. fuscata and Leptocythere spp. present at East Hyde (13), and $C$. torosa, C. fuscata, S. aculeata and L. elliptica present at Clacton (14). The absence of salinity indicators at Ebbsfleet may be explained by the evidence that this assemblage may have accumulated somewhat earlier in the interglacial than those at other localities (Whittaker et al. 2013), when sea-level was lower and saline tidal waters had not reached this far up the palaeo-Thames.

The occurrence of C. torosa in MIS 11 lake sediments at Marks Tey, as the sole brackish component of an otherwise freshwater assemblage, was recorded by Robinson (1978) who speculated that it might signify a connection with the saline waters of the Thames estuary. The precise stratigraphical location (Hoxnian Interglacial or post-Hoxnian?) and palaeoenvironmental significance (brackish or freshwater?) of this occurrence are currently being investigated (Horne et al. 2014).

\section{Comparison with ostracod biofacies in the modern Thames Estuary}

Of seven ostracod biofacies defined by Kilenyi (1969) in the modern Thames Estuary, the first four are of particular relevance and are summarized below and in Figure 2. Some taxonomic names have been updated to conform to current usage.

\section{Biofacies I}

Biofacies I was defined on the basis of a single sample and is thought to characterize the inner estuarine tidal river where the water is highly variable fresh to brackish but never fully marine. The biocoenosis consists largely of freshwater/oligohaline species dominated by Ilyocypris gibba, Candona neglecta Sars and Limnocythere inopinata (Baird); it also includes the brackishwater taxa $S$. aculeata and Heterocypris salina (Brady). The thanatocoenosis is dominated by $C$. torosa, in association with marine/estuarine species including Leptocythere castanea.

\section{Biofacies II}

Biofacies II occupies the central part of the Inner Estuary where fluctuating brackish-water salinities prevail. The biocoenosis comprises $C$. torosa (very common), marine/estuarine taxa including Leptocythere (very common) with several other common or rare taxa, and rare freshwater/oligohaline species. The thanatocoenosis consists of brackish/marine species.

\section{Biofacies III}

Biofacies III equates to the eastern or outer part of the Inner Estuary, with salinities varying from brackish to almost fully marine. The biocoenosis is dominated by C. torosa (40\%) and Pontocythere elongata (Brady) (a marine/estuarine species), with other marine/ estuarine taxa. The thanatocoenosis comprises two freshwater taxa, C. neglecta and I. gibba.

\section{Biofacies IV}

Biocoenosis IV occupies the largest part of the Outer Estuary where salinities are close to normal marine; the biocoenosis comprises marine/estuarine species dominated by $P$. elongata, with $C$. torosa constituting only $7 \%$ of the assemblage overall, although it is the subdominant species in the west and decreases in abundance eastwards. The thanatocoenosis consists of one freshwater taxon (C. neglecta).

It is important to understand that Kilenyi recorded no living ostracods in his study (which he attributed to the sampling methods used) and determined his biocoenoses using several criteria including staining with Rose Bengal (to identify specimens living at the time of collection; he found this unreliable), valve:carapace ratio, juvenile:adult ratio, mode of preservation, and opacity or colour of shells. Although he stressed that his biocoenoses were interpreted in the widest sense of the term, and equated to Wagner's (1957, 1964) biocoenosis plus thanatocoenosis I, they were considered to represent essentially in situ assemblages. Strictly speaking, a biocoenosis (life assemblage) can only be represented by living specimens; Kilenyi's terminology has been followed in the above descriptions of his biofacies, but his 'biocoenoses' are, in fact, thanatocoenoses (in situ death assemblages) while his 'thanatocoenoses' are really taphocoenoses (transported death assemblages) (Boomer et al. 2003).

Despite evidence of an increase in salinity indicator species downstream of the Thames/Medway confluence during both MIS 9 and MIS 11 (Fig. 1), the abundance of freshwater species (cf. 'rare freshwater species' in Biofacies II) at all sites suggests a broad palaeoenvironment most similar to Kilenyi's (1969) Biofacies I: a tidal river with highly variable fresh to brackish water and an in situ freshwater ostracod assemblage, with estuarine/marine species (including C. torosa) being transported post-mortem. The ubiquitous presence of freshwater taxa may partly be the result of their post-mortem transport down the river, but the absence of marine or outer estuarine taxa transported upstream by tidal currents is sufficient to rule out Biofacies II.

If Kilenyi's biofacies are correct, i.e. freshwater-dominated assemblages and in situ salinity indicators being mutually exclusive, then there may be no exact modern analogue in the Thames for the palaeochannels of the Thames/Medway system during the MIS 9 and MIS 11 interglacials. However, Biofacies I is defined on the basis of a single sample only. Furthermore, given the lack of true 


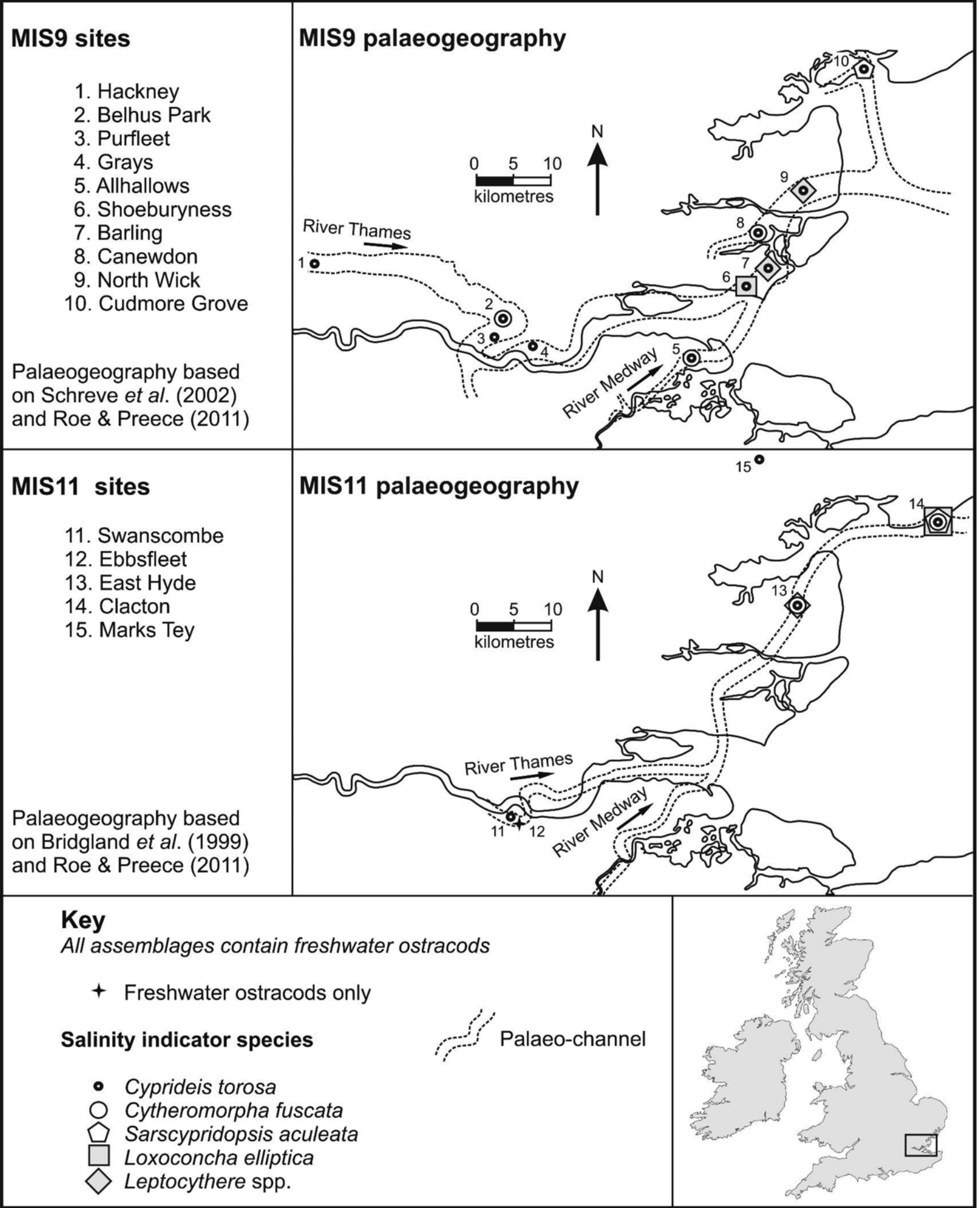

Fig. 1. Distribution of ostracod species indicative of brackish water in otherwise freshwater assemblages of MIS 9 (ten sites) and MIS 11 (five sites) age.

biocoenoses in Kilenyi's definitions, the relationship between the modern biofacies and palaeo-assemblages remains unclear.

It is notable that $C$. fuscata, present in six MIS 9 sites and one MIS 11 site, was not identified in the modern estuary by Kilenyi (1969); indeed its living distribution in Britain is restricted to a single known occurrence in Norfolk (Boomer \& Horne 1991).

\section{Noding}

Kilenyi (1972) reported that specimens from the modern Thames Estuary showed a wide range of variation in the development of nodes (swellings on the external surface of the carapace); he cited an example of a sample of living C. torosa collected from a ditch 


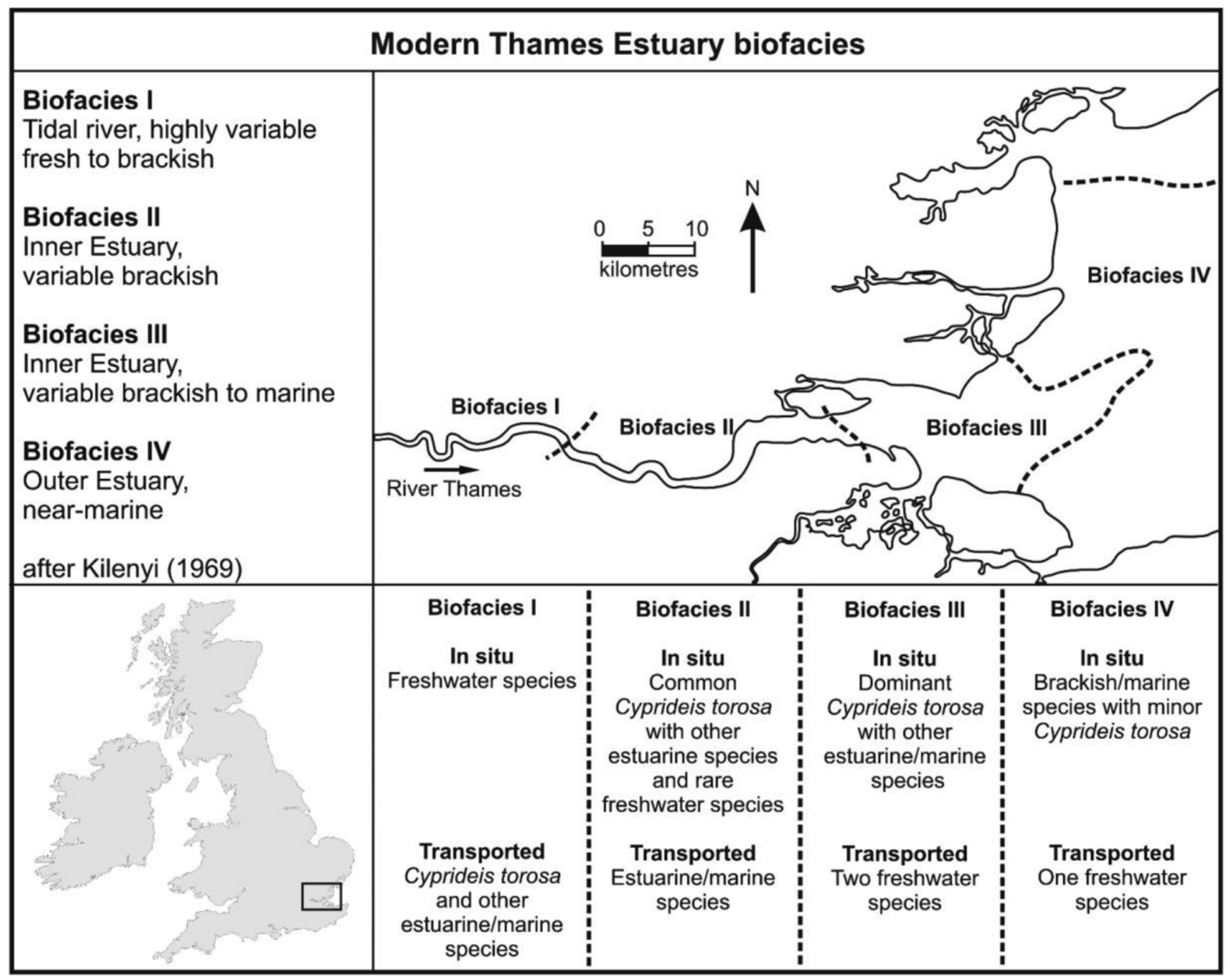

Fig. 2. Ostracod biofacies of the modern Thames Estuary (after Kilenyi 1969).

behind the sea wall at Decoy Point in the Blackwater Estuary (a tributary of the Thames Estuary) which comprised 296 individuals among which was only a single, juvenile, noded valve. He also stated that in the modern Thames Estuary noded forms only constituted about $1 \%$ of the total (41 out of 3313 specimens). He was unable to find any correlation between salinity and the distribution of noded specimens (bear in mind that he was mainly considering dead assemblages, including some that had been subjected to post-mortem transport, not living specimens).

Noding (or lack of it) in C. torosa at Pleistocene sites within the Thames-Medway river system is of great interest, and seems to present a rather different picture from what might be found at the present day. Jones (1850) originally described C. torosa from the MIS 9 ('Purfleet Interglacial') site at Grays, where the valves are exclusively noded, with the maximum seven positions of noding being exhibited. In all the sites of this interglacial (Fig. 1), in our experience, the ostracod is similarly noded, although in the North Wick (North Wycke) borehole we have seen smooth forms beginning to appear and outnumbering noded forms towards the top of the sequence. In the MIS 9 assemblage at Purfleet, Huw Griffiths (in Schreve et al. 2002) found the majority of C. torosa specimens to be well noded, as did Bridgland et al. (2013). In the earlier MIS 11 (Hoxnian Interglacial) Thames-Medway sites (Fig. 1), C. torosa is again highly noded, with all seven nodes developed on each valve.

Cyprideis torosa also occurs in younger Pleistocene sites of the Thames-Medway system. Of the MIS 7 ('Aveley') interglacial, only two sites (from Aveley itself) are known to us. The major collection of Eric Robinson (formerly of University College London), now housed in the Natural History Museum, London, has been revisited. We also have access, thanks to Simon Parfitt (Natural History Museum, London), to material from a section prepared for a Geologists' Association fieldtrip to Aveley in 1994. In both sets of samples, when it occurs, the valves of C. torosa are invariably entirely smooth. Most recently, one of us (JEW) has had the opportunity, again through the good offices of Simon Parfitt, to examine MIS 5e (Ipswichian Interglacial) material from the famous Trafalgar Square site in London (in particular an excavation at Canadian Pacific House, collected some time ago); in this case $C$. torosa is strongly noded.

What are we to make of this? Clearly, part of the explanation must be the salinity. As already discussed above, the highly noded forms indicate low brackish conditions, on or near the limit of tidal reach within the Thames-Medway system. This is corroborated by the fact that these same sections, where noded $C$. toros $a$ occurs, also contain non-marine ostracods which can tolerate such conditions, but the tidal limit may have been variable, moving up and down the estuary perhaps on a seasonal basis. At North Wick farm within the Burnham Channel the upper part of the MIS 9 sequence, with a preponderance of smooth valves, also contains Leptocythere lacertosa (Hirschmann) and small foraminifera and this suggests the site could have been a little more saline (see Fig. 1). With regard to MIS 7, we have few localities and little is known of the palaeogeography of the river at that time, as is also the case in the 
Ipswichian, but with smooth forms at Aveley and noded ones at Trafalgar Square, C. torosa suggests there is a salinity regime difference between the two sites. This, however, cannot be the full answer. Is substrate also part of the picture? The facies of the MIS 11 and MIS 9 sediments always seems to indicate a sandy substrate, as does MIS 5e. Unfortunately, we have little of the original sediment from Aveley (there is none left of the original sediment that Robinson studied so extensively), and the brick pit is now flooded. In the Geologists' Association section we have recorded silt and silty sand for the samples containing smooth C. torosa.

Today, in our experience, noded C. torosa is not found within the Thames-Medway estuaries. However, we have mainly sampled the soft mud of tidal creeks and saltmarsh. Kilenyi's (1972) exceedingly rare records of noded forms probably represent reworking. For that matter, whether relevant or not, C. fuscata, another ostracod of tidal rivers and a common associate of $C$. torosa in the Pleistocene (see above, and Fig. 1), is (as far as we know) completely absent in the modern Thames-Medway. Something in the ecological dynamics has clearly changed.

\section{Conclusions}

In spite of the widely recognized value of $C$. torosa as a precise palaeosalinity indicator, its use in mapping palaeosalinity regimes onto estuarine palaeogeography is constrained by taphonomic considerations. Nevertheless, its use in combination with other palaeosalinity indicators has provided valuable insights regarding the palaeosalinity regimes of the lower River Thames and River Medway during the MIS 9 and MIS 11 interglacials. All of the assemblages considered in this study are best matched to Biofacies I of Kilenyi (1969) which, although poorly defined, is indicative of predominantly freshwater river conditions with some limited tidal influence; the main estuary must have existed further east and NE than the present study area and all of its deposits must be submerged today. Assemblages such as that recorded at Purfleet (MIS 9), comprising in situ noded $C$. torosa in association with an otherwise freshwater fauna, appear to have no recorded modern analogue in the present-day Thames Estuary. Whether this is due to different conditions in the past, or simply a lack of adequate sampling in the upper reaches of the modern estuary, may be a suitable question for future research.

\section{Acknowledgements and Funding}

GB's contribution was supported by a Queen Mary University of London $\mathrm{PhD}$ studentship.

\section{Scientific editing by Alan Lord}

\section{References}

Alm, G. 1912. Zur Kenntnis der Süsswasser-Cytheriden. Zoologischer Anzeiger, 39, 668-673.

Alm, G. 1916. Monographie der schwedischen Süsswasser-Ostracoden. Zoologiska Bidrag Fran Uppsala, 4, 1-248.

Athersuch, J., Horne, D.J. \& Whittaker, J.E. 1989. Marine and Brackish Water Ostracods. Synopses of the British Fauna (New Series), 43. E.J. Brill, Leiden.

Bates, M.R., Keen, D.H., Whittaker, J.E., Merry, J.S. \& Wenban-Smith, F.F. 2002. Middle Pleistocene molluscan and ostracods faunas from Allhallows, Kent, UK. Proceedings of the Geologists' Association, 113, 223-236.

Boomer, I. \& Horne, D.J. 1991. On Cytheromorpha fuscata (Brady). A StereoAtlas of Ostracod Shells, 18, 49-56.

Boomer, I., Horne, D.J. \& Slipper, I.J. 2003. The use of ostracods in palaeoenvironmental studies, or what can you do with an ostracod shell? In: Park, L.E. \& Smith, A.J. (eds) Bridging the gap: trends in the ostracode biological and geological sciences. The Paleontological Society Papers, 9, 153-179.

Brady, G.S. 1868. On the Crustacean fauna of the salt marshes of Northumberland and Durham. Natural History Transactions of Northumberland and Durham, 3, 120-136.

Brady, G.S. \& Robertson, D. 1870. The Ostracoda and Foraminifera of tidal rivers. Annals and Magazine of Natural History, Series 4, 6, 1-33.
Brady, G.S., Crosskey, H.W. \& Robertson, D. 1874. A monograph of the postTertiary Entomostraca of Scotland (including species from England and Ireland). Palaeontographical Society, Monograph, 1874.

Bridgland, D.R., Field, M.H., Holmes, J.A., McNab, J., Preece, R.C., Selby, I. \& Wymer, J.J. 1999. Middle Pleistocene interglacial Thames-Medway deposits at Clacton-on-Sea, England; reconsideration of the biostratigraphical and environmental context of the type Clactonian Palaeolithic industry. Quaternary Science Reviews, 18, 109-146.

Bridgland, D.R., Preece, R.C. et al. 2001. Middle Pleistocene interglacial deposits at Barling, Essex. UK: evidence for a longer chronology for the Thames terrace sequence. Journal of Quaternary Science, 16, 813-840.

Bridgland, D., Harding, P. et al. 2013. An enhanced record of MIS 9 environments, geochronology and geoarchaeology: data from construction of the High Speed 1 (London-Channel Tunnel) rail-link and other recent investigations at Purfleet, Essex, UK. Proceedings of the Geologists Association, 124, 417-476.

Elofson, O. 1969. Marine Ostracoda of Sweden with a special consideration of the Skagerrak. Israel Program for Scientific Translations. Translated from German: Zoologiska Bidrag fran Uppsala, 1941.

Frenzel, P., Schulze, I. \& Pint, A. 2012. Noding of Cyprideis torosa valves (Ostracoda) - a proxy for salinity? New data from field observations and a long-term microcosm experiment. International Review of Hydrobiology, 97, 314-329.

Green, C.P., Branch, N.P. et al. 2006. Marine isotope stage 9 environments of fluvial deposits at Hackney, north London, UK. Quaternary Science Reviews, 25, 89-113.

Griffiths, H.I. 1995. European Quaternary freshwater Ostracoda: a biostratigraphic and palaeobiogeographic primer. Scopolia, 34, 1-168.

Hagerman, L. 1967. Ostracods of the Tvärminne area, Gulf of Finland. Commentationes Biologicae, Societas Scientiarum Fennica, 30, 1-13.

Hijmans, R.J., Guarino, L., Cruz, M. \& Rojas, E. 2001. Computer tools for spatial analysis of plant genetic resources data: 1. DIVA-GIS. Plant Genetics Resources Newsletter, 127, 15-19.

Horne, D.J. \& Boomer, I. 2000.The role of Ostracoda in saltmarsh meiofaunal communities. In: Sherwood, B.R., Gardiner, B.G. \& Harris, T. (eds) British Saltmarshes. Forrest Text, Cardigan, for the Linnean Society of London, 182-202.

Horne, D.J., Bal, D., Benardout, G., Huckstepp, T., Lewis, S.G. \& March, A 2014. Ostracods from Marks Tey: palaeoenvironmental and palaeoclimate implications. In: Bridgland, D.R., Allen, P. \& White, T.S. (eds) The Quaternary of the Lower Thames \& eastern Essex: Field Guide. The Quaternary Research Association, London, 100-108.

Jones, T.R. 1850. Description of the Entomostraca of the Pleistocene beds of Newbury, Copford, Clacton, and Grays. Annals and Magazine of Natural History, Series 2, 6, 25-28.

Jones, T.R. 1857. A monograph of the Tertiary Entomostraca of England. Palaeontographical Society (Monograph) for $\mathbf{1 8 5 6}$.

Jones, T.R. \& Sherborn, C.D. 1889. A supplementary monograph of the Tertiary Entomostraca of England. Palaeontographical Society (Monograph), 1889.

Kilenyi, T.I. 1969. The problems of ostracod ecology in the Thames Estuary. In: Neale, J.W. (ed.) The Taxonomy, Morphology and Ecology of Recent Ostracoda. Oliver \& Boyd, Edinburgh, 251-267.

Kilenyi, T.I. 1972. Transient and balanced genetic polymorphism as an explanation for variable noding in the ostracode Cyprideis torosa. Micropaleontology, 18, 47-63.

Kilenyi, T.I. \& Whittaker, J.E. 1974. On Cyprideis torosa (Jones). A Stereo-Atlas of Ostracod Shells, 22, 21-32.

Krzymińska, J. \& Namiotko, T. 2012. Late Glacial and Holocene Ostracoda of the Gulf of Gdańsk, the Baltic Sea, Poland. International Review of Hydrobiology, 97, 301-313.

Lord, A.R., Horne, D.J. \& Robinson, J.E. 1988. An Introductory Guide to the Neogene and Quaternary of East Anglia for Ostracod Workers. British Micropalaeontological Society, Aberystwyth

McKillop, W.B., Patterson, R.T., Delorme, D.L. \& Nogrady, T. 1992. The origin, physico-chemistry and biotics of sodium chloride dominated saline waters on the western shore of Lake Winnepegosis, Manitoba. The Canadian FieldNaturalist, 106, 454-473.

Meisch, C. 2000. Freshwater Ostracoda of Western and Central Europe. Süßwasserfauna von Mitteleuropa 8/3. Spektrum Akademischer Verlag, Heidelberg, Germany.

Namiotko, T., Danielopol, D.L., Belmecheri, S., Gross, M. \& von Grafenstein, U. 2012. On the Leptocytheridae ostracods of the long-lived Lake Ohrid: A reappraisal of their taxonomic assignment and biogeographic origin. International Review of Hydrobiology, 97, 356-374.

Neale, J.W. \& Delorme, L.D. 1985. Cytheromorpha fuscata: a relict Holocene marine ostracod from freshwater inland lakes of Manitoba Canada. Revista Española de Micropaleontología, 17, 41-64.

Penkman, K.E.H., Preece, R.C et al. 2013. An aminostratigraphy for the British Quaternary based on Bithynia opercula. Quaternary Science Reviews, 61, 111-134.

Pint, A., Frenzel, P., Fuhrman, R., Scharf, B. \& Wennrich, V. 2012. Distribution of Cyprideis torosa (Ostracods) in Quaternary athalassic sediments in Germany and its application for palaeoecological reconstructions. International Review of Hydrobiology, 97, 330-355. 
Robinson, E. 1978. The Pleistocene. In: Bate, R.H. \& Robinson, E. (eds) A Stratigraphical Index of British Ostracoda. Seel House Press, Liverpool, 451-472.

Roe, H.M. 2001. The late Middle Pleistocene biostratigraphy of the Thames valley, England: new data from eastern Essex. Quaternary Science Reviews, 20, 1603-1619.

Roe, H.M. \& Preece, R.C. 2011. Incised palaeo-channels of the late Middle Pleistocene Thames: age, origins and implications for fluvial palaeogeography and sea-level reconstruction in the southern North Sea basin. Quaternary Science Reviews, 30, 2498-2519.

Roe, H.M., Coope, G.R., Devoy, R.J.N., Harrison, C.J.O., Penkman, K.E.H., Preece, R.C. \& Schreve, D.C. 2009. Differentiation of MIS 9 and MIS 11 in the continental record: vegetational, faunal, aminostratigraphic and sea-level evidence from coastal sites in Essex, UK. Quaternary Science Reviews, 28, 2342-2373.

Roe, H.M., Penkman, K.E.H., Preece, R.C., Briant, R.M. \& Wenban-Smith, F.F. 2011. Evolution of the Thames estuary during MIS 9: insights from the Shoeburyness area, Essex. Proceedings of the Geologists' Association, 122, $397-418$.

Sars, G.O. 1925. An Account of the Crustacea of Norway, 9, Ostracoda, parts 1112, Cytheridae (continued). Bergen Museum, 177-208.

Schreve, D.C., Bridgland, D.R. et al. 2002. Sedimentology, palaeontology and archaeology of late Middle Pleistocene River Thames terrace deposits at Purfleet, Essex, UK. Quaternary Science Reviews, 21, 1423-1464.

Smith, A.J. \& Horne, D.J. 2002. Ecology of marine, marginal marine and nonmarine ostracodes. In: Holmes, J.A. \& Chivas, A.R. (eds) The Ostracoda: Applications in Quaternary Research. American Geophysical Union, Geophysical Monograph, 131, 37-64.

Theisen, B.E. 1966. The life history of seven species of ostracods from a Danish brackish water locality. Meddelelser fra Danmarks Fiskeri og Havunders, 4 , $215-270$.

Wagner, C.W. 1957. Sur les ostracodes du Quaternaire récent des Pays-Bas et leur utilisation dans l'étude géologique des dépôts Holocènes. Mouton \& Co., The Hague.

Wagner, C.W. 1964. Ostracods as environmental indicators in Recent and Holocene estuarine deposits of The Netherlands. Pubblicazioni Della Stazione Zoologica di Napoli, 33(suppl.), 480-495.

White, T.S., Preece, R.C. \& Whittaker, J.E. 2013. Molluscan and ostracod successions from Dierden's Pit, Swanscombe: insights into the fluvial history, sea-level record and human occupation of the Hoxnian Thames. Quaternary Science Reviews, 70, 73-90.

Whittaker, J.E., Horne, D.J. \& Wenban-Smith, F. 2013. Ostracods and other microfossils. In: Wenban-Smith, F. (ed.), The Ebbsfleet Elephant. Excavations at Southfleet Road, Swanscombe in advance of High Speed 1, 2003-4. Oxford Archaeology Monograph, 20, 275-289. 